\title{
Grants and Opportunities
}

\section{Call for applications for Cambridge Masters in Conservation Leadership, October 2018}

The Cambridge Masters in Conservation Leadership is a full-time, 11-month course, aimed at graduates with leadership potential who have at least 3-5 years of relevant experience in conservation. The unique features of this course are its delivery by a partnership between university departments and conservation organizations, and its focus on issues of management and leadership. The goal is not only to develop conservationists with enhanced research skills and greater awareness of the complex drivers of biodiversity loss but also to develop their ability to act and lead effectively. This includes the development of professional management and leadership skills, including strategic planning, finance, HR management, innovation, entrepreneurship and the management of change. The course fosters the leadership potential of its students by promoting their capacity to understand the links amongst the drivers of biodiversity loss, and to think creatively about conservation solutions across organizational and political boundaries and economic sectors.

This Masters has its academic base in the Department of Geography at the University of Cambridge, which collaborates with partners in the Cambridge Conservation Initiative to deliver the course. The Masters programme has dedicated teaching space in the new Conservation Campus, in the David Attenborough Building, co-located alongside c. 500 conservationists from the Cambridge Conservation Initiative.

Application for entry to the course in October 2018 opens in September 2017. Several full or partial scholarships are available for applicants, and further funds are available from the Cambridge Trusts. To be eligible for all scholarships applicants must apply by early December 2017. Full details of the course, how to apply, and funding opportunities can be found at www.geog.cam.ac.uk/graduate/mphil/ conservation

\section{Call for applications for 2018 Conservation Leadership Programme Conservation Awards}

The Conservation Leadership Programme (CLP) is a training and capacity-building programme that targets earlycareer conservationists from developing countries who demonstrate leadership potential. This partnership of BirdLife International, Fauna \& Flora International and the Wildlife Conservation Society has been supporting young conservationists for over 30 years by awarding project funding, training, networking and mentoring support.

In 2018 CLP will be granting Future Conservationist Awards (up to USD 12,500 each) for new applicants and Conservation Follow-up Awards (up to USD 20,000 each) for previous CLP Future Conservationist Award winners. CLP will also offer one Conservation Leadership Award (up to USD 40,000) to a previous CLP Follow-up Award winner.
The application deadline for 2018 awards will be in November 2017 and application materials will be available on the CLP website in August. Awards will be announced in April 2018. Applicants are encouraged to contact a CLP staff member for advice well before the application deadline. Staff members can help teams determine if their project fits the specified criteria, offer advice on methods and project activities, and put teams in touch with local partner offices or other experts who can provide additional advice.

Eligibility criteria, award guidelines and the application form are available at www.conservationleadershippro gramme.org; e-mail clp@birdlife.org.

\section{Call for applications for the Whitley Awards 2018}

The Whitley Fund for Nature is a UK registered charity offering Whitley Awards to outstanding nature conservation leaders in the developing world. Through the Awards, which comprise a project grant of GBP 35,00o over 1 year, Whitley Fund for Nature aims to identify, recognize and fund the most dynamic, inspirational and effective conservation leaders and their teams working in middle- and low-income countries; to focus on local leaders who are nationals of the countries or regions where they are working; to support work that is founded on scientific research, practical action and community involvement, with a proven track record of success; to fund pragmatic projects that aim to have a measurable, long-lasting impact; and to raise the national and international profile of winners and help them network effectively, educate others, and raise public awareness of the problems facing biodiversity and ecosystems worldwide. Whitley Fund for Nature places a high value on projects that have achieved groundswell grassroots support. Often those funded have helped set up a local NGO but are now ready to scale up significantly.

Whitley Awards are the result of a competitive process and are presented at the annual Whitley Awards Ceremony at the Royal Geographical Society in London each spring. Winners join a growing network of over 185 winners in more than 80 countries. Whitley Fund for Nature stays in close contact with winners and the most successful can apply for further funding through our Continuation Funding programme, which awards grants of up to GBP 70,000 over 2 years.

The deadline for applications for the next Whitley Awards is 31 October 2017. Potential applicants can read about the eligibility requirements at www.whitleyaward. org, where the application form and detailed guidance notes will be available from August.

Please note that Whitley Fund for Nature does not fund undergraduate projects, expeditions, Master's research, or pure-research PhD work. If you have any questions regarding the Whitley Awards, please email Alison Rosser at alison@whitleyaward.org 